\title{
The Role of Brand and Company Image in Building Brand Loyalty through Service Quality and Brand Trust
}

\author{
Muhammad Ahmad Fawad Sheikh \\ Department of Management Sciences, The Islamia University of Bahawalpur, Pakistan \\ Muhammad Ahsan Fawad Sheikh \\ Department of Management Sciences, The Islamia University of Bahawalpur, Pakistan
}

Muhammad Rizwan (Corresponding author)

Lecturer, Department of Management Sciences,

The Islamia University of Bahawalpur, Pakistan

E-mail: rizwan.arshad@iub.edu.pk

Qasim Maqsood

Department of Management Sciences, The Islamia University of Bahawalpur, Pakistan

Doi:10.5296/ jsr.v5i1.6571 URL: http://dx.doi.org/10.5296/ jsr.v5i1.6571

\begin{abstract}
In today's competitive world brand loyalty is the only tool for organizations to gather customers around them. We cannot describe brand loyalty completely by a consumer's intention to repurchase a specific brand. Peoples intention to purchase a specific brand affected by many variables; some of these variables are discussed in this study. The purpose of the current study is to explore the impact of Brand image and company image on service quality and the impact of service quality on brand trust, followed by the relationship between brand trust and brand loyalty. Results of the study reveals that Brand image and company image have significant impact on service quality where service quality significantly affects brand trust. This study also explore that there is a direct positive impact of brand trust and customer satisfaction on brand loyalty.
\end{abstract}

Keywords: Brand Image, Company Image, Service Quality, Brand trust, Customer Satisfaction, Brand Loyalty 


\section{Introduction}

Brands are intangible assets of companies and use of these brands to make good relationships with customer is proven a good market strategy. According to Mitchell (1997) good relationship marketing as an act of gathering customers strongly around a brand, and get the loyalty of customers by concentrating on customer needs. Customer experiences are major driving forces behind their choice associated tore-purchase of brand and use again of that brand. Many companies have failed to adopt the marketing mix that actually describes demands of customers, as the customer would love to buy the way he wants it to. It is commonly used as a marketing benchmark of a company's efficiency.

Consistent pattern of purchase of a specific brand over time and favorable attitude towards a brand are indicated by brand loyalty. When a brand fulfills the expectations, personality or self-image of the customer or when the brand offers satisfying and unique benefits that a consumer looks for, brand loyalty is developed. When a customer buys the products of the same organization even if alternatives are available with better quality than the customer is said to be brand loyal.

Companies through branding and by focusing on customer's needs and wants can create product differentiation. According to Jacoby and Chestnut (1998) Customers who are brand loyal are always ready to pay more for a brand. If the brand loyal customers repeatedly buy the same brand then these companies can get more market share (Assael. 1998). Brand Loyalty provides long term advantages to companies, according to new research long term customers were less devoted to price increase.

Customers want change that's why they switch between brands, According to Customers buy Brand portfolios. Brand share provides us with only statistical probability that customers will repurchase brand as an element of portfolio brands. It does not guarantee that customers are loyal to our brand. Aside from a consumer's aptitude to repurchase a brand, we can say a customer brand loyal if customer shows high feelings towards a brand. This is than confirmed by the purchasing behavior of that customer.

The main purpose of this research is to study the brand loyalty and the relationships among brand image, company image and service quality and the effect of service quality on brand loyalty. This study also examines the relationship between customer satisfaction and brand loyalty.

In this research paper we analyze the effects of variables such as brand image, company image, service quality and customer satisfaction on brand loyalty, and the effect of brand trust on brand loyalty. Moormal et al (1993) defined brand trust is the keenness of an average customer on a brand that it will fulfill its stated function. According to Cemal Zehir and Azize Sahin (2011) giving consideration towards assessment that shows the consumer's view of elements of service such as interaction quality, physical environment quality, \& outcome quality defines service quality. Brand image creates overtime through advertising campaigns with a regular theme, and is validated by the customers' direct experience. To improve demand as a supplier, customer and employer etc and to make better image 
companies use many corporate advertising tools, resulting in customer's loyalty.

\section{Literature review}

\section{Brand loyalty}

Brand loyalty includes a positive attitude towards a brand and a regular purchase pattern of specific brand over time (Aaker, 1992). When a brand fulfill all required needs of a customer and fulfill customer's expectations and provide some unique benefits that a customer needs than brand loyalty is developed. A customer who buy the products of same brand again and again even if better alternatives are available than the customer is said to be brand loyal. Brand loyalty is important for company's competitiveness and profitability (Markey, 2000; Rizwan et al., 2013).

According to Sheth (1969) for at least three decades the significance of brand loyalty has been accepted in the marketing literature. According to Aaker (1991) discussed the role of loyalty in the brand equity development and has exclusively noted that brand loyalty leads to certain marketing benefits such as reduced marketing costs and increase new customers. According to Dick and Basu (1994) suggest other loyalty linked marketing advantages, such as positive word of mouth and greater resistance among loyal consumers to competitive strategies.

Switching barriers related to technical, psychological \&economical factors also make customers loyal towards a brand, because it makes it difficult and and costly for them to swich between brands.In another point of view customers want to continue the relationship because they may be loyal and satisfied with the brand (Fornell, 1992). With the performance of the product or service, loyalty is considered one of the ways through which customer expresses his or her satisfaction Bloemer and Kasper, (1995).

\section{Customer Satisfaction}

The definitions of satisfaction have been used in marketing regulation many years ago. According to Giese and Cote (2000) the wide deviation in defining the construct of satisfaction is best reconciled in their explanation of satisfaction as a summary affective response of unstable intensity with a time-specific point of determination and limited duration directed toward central points of the utilization of company's product. In conditions of whether that product or service has met their demands and necessities, we conceptualize satisfaction as a customer's overall measurement of a product or service. For consumer trading service, many experimental studies show that satisfaction is a forerunner of brand attitude, brand repurchase intention and brand attitudinal brand loyalty Oliver, (1980). Loyalty can enhance the satisfaction level when loyalty is measured after the continuous purchases of the same brand (LaBarbera and Mazursky, 1983). Also the research has shown that assessment of a retail service following purchase and consumption leads to two aspects of brand loyalty-- attitudinal and purchase loyalty, which plays an important role in determining whether the consumer will buy that service again (Chaudhuri\& Holbrook, 2001). Though, research on satisfaction and brand loyalty from the background of Chinese retailing services is not well known. Thus, the following hypothesis is arrived: 
H1: Customer satisfaction is positively related to brand loyalty.

\section{Brand Trust}

According to Moormal the typical customer is always ready to depend on the capability of the brand to fill its needs and demands .Moorman (1992) and Doney and Cannon (1997) both alsofocus on trust in case of doubt (e.g., when good versus better differences among brands take place.) Trust decreases the ambiguity in an environment in which consumers feel especially susceptible because they know trusted brand will meet their demands. Doney and Cannon (1997) propose that the construct trust in consumer's mentality involves a "calculative process" based on the ability of an object. (e.g. a brand) to carry on to meet its obligations and on the estimation of the costs versus rewards of staying in the relationship. At the same time, Doney and Cannon denoted that trust involves an inference regarding the benevolence of the firm to fully meet the needs and demands of customer.

Brand trust creates to brand loyalty because trust creates exchange relationships that are extremely valued (Morgan, 1994). Trust is an import variable in relationship exchange and commitment is also kept in reserve for such valued associations that's why we should consider trust an important variable. In this relation, Moorman, (1992) and Morgan (1994) said that in trust creates loyalty in business to business relations. People show higher level of commitment to well-known brands and are often ready to higher prices.

H2: Brand Trust is positively associated with Brand Loyalty.

\section{Service Quality}

According to Ruats, (2008) Facilitating with higher quality products to consumer with reliable excellent services will cause competitive advantages for service organizations. Most significantly competitive advantages include competitive barriers, providing best quality products, explanatory marketing costs \& consumer's loyalty. Service quality assess that the consumer's conceptions of essentials of service such as interaction quality, outcome quality \& physical environment quality. These fundamentals are in turn assessments based on particular service quality dimensions; consistency, guarantee, reaction, tangibles \& understanding. Parasuraman (1988) defined service quality as universal findings or attitude relation to the whole superiority of the service. According to research by Lefkowit and Clark (1998) and Morrall (1993) to differentiate services as alike as products, no one can differentiate them according to their name or logo but also in terms of a set of consumer's perceptions that are defined well.

Little empirical research has defined the association among service quality, brand trust and brand loyalty. With respect to behavioral intentions in service settings, Zeithaml proposed a comprehensive \& multi-dimensional framework of consumer behavioral intentions in services.

This framework was at first compromised these four main dimensions: word-of-mouth communications, price sensitivity, complaining behavior and purchase intention.

H3: Service quality is directly associated with Brand trust. 


\section{Mll Macrothink}

\section{Brand Image}

According to Thaker (2006) BI can be a notion of natural traits and has a matchless relation to brand identity concept. Aaker explains that the brand identity as a set of human traits which exists in a brand. Personality stimulation judgments explains that why a customer emotionally depends on a brand rather than any other else (Brodie et al, 2009).Brand Image is a set of associations that actually structured in some meaningful way (Aaker, 1992).

Gardner and Levy have been credited (Levy 1958) with crystallizing "brand image" in a significant way in their classic 1955 article. Criticizing old researches for being too superficial in its focus on stereotypical purchase reasons \& they suggested that it was time to scratch beneath the surface and identify more enduring motivations for purchase. Products had a psychological and social nature as well as a physical one \& that the sets of feelings, thoughts and attitudes that consumers had about brands, their perception of brands, were critical to purchase choice.

In drawn model, brand image namely the relations are existing due to which the brand and logo awareness and distinguish them from services. (Brodie et al, 2009).

H4: Brand image is positively associated with Service Quality.

\section{Company Image}

Dacin (1997) said that the subjective judgment of customers' thoughts and norms of society and culture define the company image. The capability of brand is define as its ability in product's assembling \& delivery. Social norms relate to organizing society-referred affairs. Service quality is directly influences by corporate image (Gray ER, 2003). The optimistic influence of corporate's image on service quality is very essential because of external marketing has a great influence on Corporate's Image (Kim J, hyun y 2010).

Then, there are relations on company's image which involve company's credibility rather than service providing characteristics (Brudei et al, 2009).

H5: Company image is positively associated with Service Quality.

\section{Research Methodology}

The recent research is descriptive in nature. Descriptive research can be described as explaining something, some phenomenon, or any specific scenario. Descriptive researches explain the existing scenario rather than interpreting and creating judgments (Creswell, 1994). The purpose of the descriptive research is authentication of the constructs that reflect the existing scenario.

\section{Data Collection and sample}

The recent research utilizes a non-probability sampling technique that is convenience sampling. Convenience sampling is a sampling technique, which collects the relevant information from the units of the study that are easily available (Zikmund, 1997). 


\section{Macrothink}

Convenience sampling is normally used to collect great number of completed surveys speedily and with economy (Lym etal., 2010).

The data was collected from Pakistani nationals through a personally administered questionnaire in the Pakistan. The questionnaires were distributed among 180 respondents in Bahawalpur\& the respondents are selected based on the criteria above mentioned. Before distributing the questionnaires, the purpose of study \& questions were explained to the respondents so they can easily fill the questionnaire with relevant responses. A total of 153 questionnaires were selected and rest of the questionnaires was not included in the further analysis due to in incomplete or invalid responses. The questioners were distributed in Bahawalpur City at The Islamia University of Bahawalpur at two Mobile Trade Markets namely Dubai Plaza and Al-Kareem Plaza, Bahawalpur.

\section{Instruments and Measures}

The survey instrument of the current study address two major purposes: First is to analyze the relationships of different variables with Brand Loyalty. Second, to gather information about the different characteristics of the respondents that can be used to understand the variations in different categories. The questionnaire contains two sections. Section 1 has different personal and demographic variables\& the section will obtain the respondent's information about gender, age, income, status \& education.

Section 2 has the latent variables that are essential in the current study. These variables contain Brand image, Company's image, Service quality, Perceived quality, Brand trust, Customer satisfaction and Brand loyalty .This section of the study is developed based on the past literature and already used questionnaires.

The scales of the study were adopted from the previous literature and published studies. The first variable of the study is Brand Image having five items and this scale was taken from Bian, et al., 2009. The Second variable is Company Image having six items was taken from Bian, et al., 2009. The third variable is Service quality having four items was taken from Gupta, S. (1988). The fourth variable is Brand trust having four items and was taken from Chanduhuri and Holbrook,(2001). The fifth variable is Customer satisfaction having two items was taken from Ragunathan and Irwin(2001) and the last variable Brand loyalty with six factors and this scale was taken from Chaudhuri and Holbrook, 2001.

\section{Procedure}

The questionnaires were distributed among 180 respondents at The Islamia University of Bahawalpur and two Mobile Trade Markets in Bahawalpur namely Dubai Plaza and Al-Kareem Plaza. A total of 153 questionnaires were selected and rest of the questionnaires was not included in the further analysis due to in incomplete or invalid responses. After collecting the completed questionnaires, these questionnaires were coded and entered into SPSS sheet for further analysis.

\section{Reliability Analysis}

The Cronbach's alpha of Brand Loyalty questionnaire items is more than acceptable and 
recommended value 0.50 by Nunnally (1970) and 0.60 by Moss et al. (1998). This shows that all the 27 items were reliable and valid to measure the opinions of respondents towards Brand Loyalty.

\section{Table 1: Reliability of Measurements Instrument}

\begin{tabular}{|l|l|l|}
\hline Scales & Items & Cronbach Alpha \\
\hline Brand Image & 5 & 0.790 \\
Company Image & 6 & 0.798 \\
Service Quality & 4 & 0.775 \\
Brand Trust & 4 & 0.817 \\
Customer Satisfaction & 2 & 0.787 \\
Brand Loyalty & 6 & 0.874 \\
\hline
\end{tabular}

\section{Results and analysis}

\section{Profile of the Respondents}

Personal and demographic information such as gender, age, education level and status are presented in the following table (Table 2).

Table 2: Profile of the Respondents

\begin{tabular}{|l|l|l|l|}
\hline & Category & Frequency & Percentage \\
\hline Variable & & & \\
\hline Gender & Male & 73 & 47.7 \\
Female & 80 & 52.3 \\
\hline \multirow{2}{*}{ Age } & $\begin{array}{l}15-20 \text { years } \\
20-25 \text { years }\end{array}$ & 79 & 32.0 \\
& $25-30$ years & 18 & 47.1 \\
$30-40$ years & 4 & 11.8 \\
& $35-40$ years & 4 & 2.6 \\
\hline
\end{tabular}




\begin{tabular}{|l|l|l|l|}
\hline \multirow{2}{*}{ Education } & Above 40 & 6 & 3.9 \\
& & & \\
\hline \multirow{2}{*}{ Status } & Matriculation & 20 & 13.1 \\
& Inter & 28 & 18.3 \\
& Bachelor & 70 & 45.8 \\
& Master & 23 & 15.0 \\
& MS/M. Phil & 12 & 7.8 \\
\hline & Student & 111 & 72.5 \\
& Employed & 27 & 17.6 \\
& Businessman & 6 & 3.9 \\
& Unemployed & 3 & 2.0 \\
& Housewife & 6 & 3.9 \\
\hline
\end{tabular}

\section{Hypothesis Testing}

\section{Customer satisfaction is positively related to brand loyalty}

According to the result of the study Customer satisfaction has a significant positive association with Brand Loyalty with $(\beta=.294)$ and $(\mathrm{p}<0.001)$ that means the Customer satisfaction contributes to more than $29 \%$ towards Brand Loyalty. So, we accept H1.

\section{Brand Trust is positively associated with Brand Loyalty}

The regression results of the study confirm the significant positive relationship between Brand Trust and Brand Loyalty with $(\beta=0.450)$ and $(\mathrm{p}<0.000)$. According to these results, Brand Trust contributes approximately $45 \%$ to Brand Trust. These results of the study validate $\mathrm{H} 2$.

\section{Service quality is directly associated with Brand trust}

While considering the significance between Service Quality and Brand Trust, the result of current studies shows that there is a significant relation between these variables with $(\beta=$ $0.663)$ and $(p<0.000)$. That means the Service quality contributes to more than $66 \%$ to Brand Trust. So H3 is accepted. 


\section{Macrothink}

\section{Brand image is positively associated with Service Quality}

Regression Analysis shows that there is a significant positive relationship between Brand Image and Service Quality with $(\beta=0.560)$ and $(\mathrm{p}<0.000)$. The results suggest that the Brand Image contribute almost $56 \%$ to Service Quality.So we validate H4.

\section{Company image is positively associated with Service Quality}

According to the result of the study Company image has a significant positive association with Service Quality with $(\beta=0.297)$ and $(\mathrm{p}<0.000)$ that means the Company image contributes to more than $29 \%$ to Service quality. So we accept the H5.

Table 3 summarizes the regression results of the study and Figure shows the graphical presentation of the structural model.

Table 3: Regression Results

\begin{tabular}{|l|l|l|l|l|l|l|}
\hline Hypothesis & Model variables & Estimate & S.E & C.R & P & Results \\
\hline $\mathrm{H} 1 \mathrm{H}$ & $\begin{array}{l}\mathrm{CS} \longrightarrow \\
\mathrm{BL}\end{array}$ & 0.294 & 0.083 & 3.364 & 0.001 & Supported \\
\hline $\mathrm{H} 2 \mathrm{BT}$ & $\mathrm{BL}$ & 0.450 & 0.094 & 5.149 & 0.000 & Supported \\
\hline $\mathrm{H} 3$ & $\begin{array}{l}\mathrm{SQ} \\
\mathrm{BT}\end{array}$ & 0.663 & 0.070 & 10.889 & 0.000 & Supported \\
\hline $\mathrm{H} 4$ & $\begin{array}{l}\mathrm{BI} \\
\mathrm{SQ}\end{array}$ & 0.560 & 0.056 & 9.109 & 0.000 & Supported \\
\hline $\mathrm{H} 5$ & $\begin{array}{l}\mathrm{CI} \longrightarrow \\
\mathrm{SQ}\end{array}$ & 0.297 & 0.066 & 4.841 & 0.000 & Supported \\
\hline
\end{tabular}

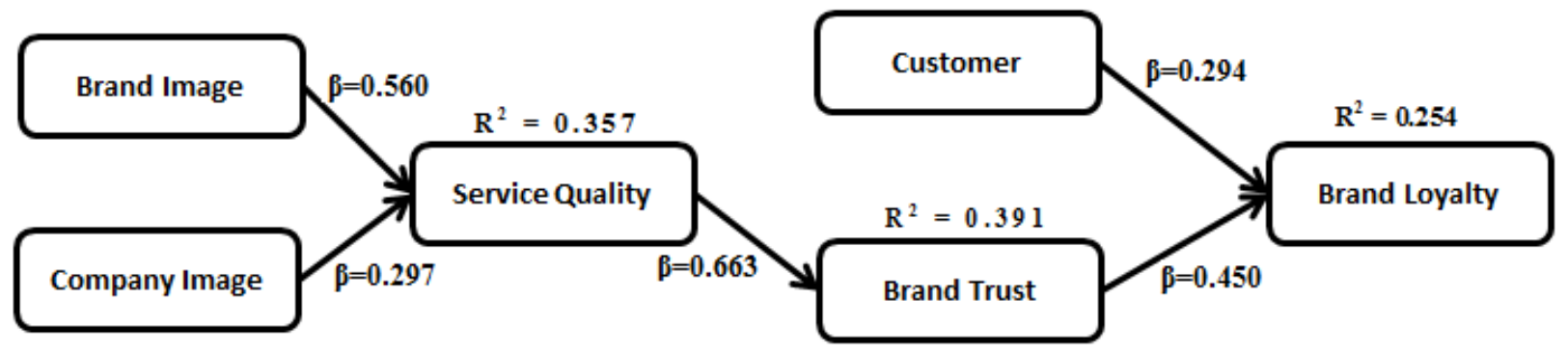

Figure 1. Structural Model Results 


\section{Macrothink}

\section{Discussion}

The purpose of this study was to explore the relationship among different variables such as Brand image, Company image, Service quality, Brand trust and Customer satisfaction. Furthermore, the influence of those constructs on the Brand Loyalty. The results of the study point out that all the variables have significant impact on brand loyalty. The other constructs were found to influence brand loyalty. These results may be clarified by the relational paradigm, and the belief of attributing human distinctiveness to brands (Aaker, 1997; Founier, 1998), which will guide to loving a brand as an emotional effect. Nokia Mobiles is considered a prestigious and trendy brand.

Following this causal model, the strategy would be increasing the brand trust, brand loyalty and brand image to enhance the emotional relationships with brands. As a result of building emotional relationships with their customers, organizations make their customers positively talk about their brands. If this is attained, the number of customer using the brand be increased and in turn the firm may report a jump in profits. All the constructs of are study are positively significant. This may be due to selected brand. To see either these constructs remain positive in the case of all brands, we can select some other brand in future study.

Finally, our results have a number of implications for brand managers. First, brand managers should undertake ongoing research with their target customers to understand the relationships between the brands and their customers. Second, brands should give careful consideration to the concept of love and how can they develop it.

\section{Limitations and Future recommendations}

All the constructs of are study are positively significant. This may be due to selected brand. To see either these constructs remain positive in the case of all brands, we can select some other brand in future study. Future research would also examine this framework on different types of brands. This research was based on the result of 153 sample results, we can conduct research with more sample size.

\section{References:}

Assael, H. (1993), Marketing Principles and Strategy, 2nd ed., Dryden Press, Hinsdale, IL.

Aaker, D. A. (1991).Managing brand equity: Capitalizing on the value of a brand name. New York: Free Press.

Aaker, J.L. (1997), "Dimensions of brand personality", Journal of Marketing Research, Vol. 34No. 3, pp. 347-56.

Aaker, D., (1991), Managing Brand Equity, San Francisco: Free Press.

Bloemer, J. , Kasper, H., (1995), “The Complex Relationship Between Consumer Satisfaction and Brand Loyalty”, Journal of Economic Psychology, Vol. 16, pp. 311-329.

Ballester-Delgado Elena and Aleman-Munuera Jose (2001) "Brand Trust In The Context of 


\section{I Macrothink}

Consumer Loyalty", European Journal of Marketing, Vol.35, No.11/2, pp.1238-1258.

Brodie R, Whittome J, Brush G (2009). Investigating the service brand : A customer value perspective. Journal of Business Research.. No 62 .pp 345-355

Brown J, DacinP(1997). The company and the product: corporate associations and consumer product responses. J Mark;61:68-84.

Chaudhuri, A. \& Holbrook, M. B. (2001) "The chain of effects from brand trust and brandaffect to brand performance: The role of brand loyalty", Journal of Marketing, Vol.65, No.2,pp.81-93.

Creswell, J. W. (1994). Research Design: Qualitative and Quantitative Approaches. Thousand Oaks, CA: Sage Publications

Dick, A.S., Basu, K., (1994), "Customer Loyalty: Toward an Integrated Conceptual Framework”, Journal of the Academy of Marketing Science, Vol. 22, No. 2, pp. 99-113.

Doney, Patricia M. and Joseph P. Cannon, (1997), "An Examination of the Nature of Trust in Buyer-Seller Relationships," Journal of Marketing, 61 (April), 35-51.

Fornell, C. (1992). A National Customer Satisfaction Barometer: The Swedish Experience. Journal of Marketing, 56(Jan), 6-21.

Giese and Cote (2000, p. 15) ,Volume 2000 No. 1 Available: http://www.amsreview.org/articles/giese01-2000.pdf

Howard, John and JagdishSheth (1969), “The Theory of Buyer Behavior".New York: John Wiley \& Sons.

Jacoby, W and. Chestnut.R. (1978) Brand Loyalty: measurement and management, John Wiley and Sons, New York.

Kim J, hyuny(2010). Amodel of investigate the influence of marketing- mix efforts and corporate image on brand equity in the software sector. Industrial marketing management

LaBarbera PA, Mazursky D (1983). A longitudinal assessment of consumer satisfaction/dissatisfaction: The dynamic aspect of the cognitive process. J. Mar. Res., 20(4): 393-404.

Levy, S.J. (1959), “Symbols for sales”, Harvard Business Review, Vol. 37 No. 4, pp. 117-24

Mitchell, A.A. and Olson, J.C. (1981), “Are product attribute beliefs the only mediator of advertising effects on brand attitude?", Journal of Marketing Research, Vol. 18 No. 3, pp. 318-32.

McAlister, L. and Pessemier, E. (1982), "Variety seeking behavior: an interdisciplinary review", The Journal of Consumer Research, Vol. 9 No. 3, pp. 311-22.

Moorman, C., R. Deshpande and G. Zaltman (1993), Factors Affecting Trust in Market Research Relationships, Journal of Marketing, 57 (January), 81-101. 


\section{$\Lambda$ Macrothink}

Morgan, R.M., \& Hunt, S.D. (1994). The commitment-trust theory of relationship marketing, Journal of Marketing,58

Oliver, R. L. (1999) "Whence consumer loyalty?",Journal of Marketing, Vol.63, Special Issue, pp.33-44.

Pritchard MP, Havitz ME, Howard DR (1999). Analyzing commitment loyalty link in service contexts. J. Acad. Mar. Sci., 27(3): 333-348.

Parasuraman, A., Zeithaml, V. A., \& Berry, L. L. (1988).SERVQUAL: A multipleitem scale for measuring consumer perceptions of service quality. Journal of Retailing, 64(1), 12-40.

Reicheld, F. F. \&Schefter, P. (2000) "E-loyalty: Your secret weapon on the web", Harvard Business Review, Vol.78, No.4, pp.105-113.

Reichheld, F., \& Markey Jr., R. G. (2000).The loyalty effect - The relationship between loyalty and profits.European Business Journal, 12(3), 134.

Rizwan, M., Ahmad, W., Tahir, S., Ali, S., Naz, A., Ain, Q. \& Peerzada, P. (2013) Antecedents of Brand Loyalty: An Empirical Study from Pakistan, International Journal of Research in Commerce, Economics and Management, 3(3), 169-174

Rizwan, M., Riaz, T., Akhter, N., Murtaza, G., Hasnain, M., Hussain, L. \& Rasheed, I. (2013) Antecedents of Brand Loyalty an Empirical Study from Pakistan, International Journal of Research in Computer Applications and Management, 3(3), 165-171

Russell-Bennett R, McColl-Kennedy JR, Coote LV (2007). Involvement, satisfaction and brand loyalty in a small business services setting. J. Bus. Res., 60(12): 1253-1260.

Russell-Bennett R, McColl-Kennedy JR, Coote LV (2007). Involvement, satisfaction and brand loyalty in a small business services setting. J. Bus. Res., 60(12): 1253-1260.

Rusta, Ahmed (1999), "the most important differences between services and goods in marketing management”, Marketing Bimonthly, vol. 5.

The Effects Of Brand Communication And Service Quality In Building Brand Loyalty Through Brand Trust; The Empirical Research On Global Brands(CEMAL ZEHIR, AZIZE SAHIN, HAKAN KITAPÇI, MEHTAP ÖZSAHIN)

Zeithaml, V. A., Berry, L. L., \&Parasuraman, A. (1996).The behavioural consequences of service quality. Journal of Marketing, 60(2), 31-46.

Zikmund, W. G. (1997). Business Research Method. Fifth ed. The Dryden press, Harcourt Brace College Publishers, Orlando, Florida. 